\title{
Production of cuticle-degrading proteases by Nomuraea rileyi and its virulence against Anticarsia gemmatalis
}

\author{
Produção de proteases degradadoras de cutícula por Nomuraea rileyi e sua virulência contra \\ Anticarsia gemmatalis
}

\author{
Ana Rita Fonseca Nunes,II Juliana Nascimento Martins ${ }^{\mathrm{I}}$ Márcia Cristina Furlaneto ${ }^{\mathrm{III}}$ \\ Neiva Monteiro de Barros $^{\mathrm{I}^{*}}$
}

\begin{abstract}
Nomuraea rileyi represents an important natural control agent of Anticarsia gemmatalis preventing populations from reaching economic threshold levels in soybean. During the processes of host infection, entomopathogenic fungi produce extracellular proteases, which degrade the host cuticle and are suggested to be virulence determinants. It was examined the production of subtilisin-like (Pr1) and trypsin-like (Pr2) proteases in two strains (NR458 and CG434) of N. rileyi and its possible role in the process of pathogenicity to this caterpillar. Fungal growth was performed in a mineral medium containing nitrate, and supplemented with the cuticle or exuviae from $\boldsymbol{A}$. gemmatalis, or with the non-cuticular substrate casein. In medium containing nitrate as sole nitrogen source, no detectable Prl-like activity occurred in the culture supernatants of the two fungal strains. However, both strains of N. rileyi produced Pr1like protease in all medium amended with exogenous nitrogen source, and it was highly expressed in the presence of insect cuticle. Pr2-like activity was significantly inferior to Prl-like activity and it was detected only in some of the media culture and incubation periods tested. In the NR458 culture supernatant the highest activity was observed in medium containing nitrate as nitrogen source. Correlation analysis between the percentage of A. gemmatalis mortality in bioassays and Prl-like protease activity of strain NR458 suggests a positive correlation for these variables.
\end{abstract}

Key words: biological control, subtilisin-like [Pr1], trypsinlike [Pr2].

\section{RESUMO}

O objetivo deste estudo foi avaliar a produção de proteases dos tipos subtilisina [Pr1] e tripsina [Pr2] por duas linhagens do fungo entomopatogênico Nomuraea rileyi e a correlação entre a atividade de $\operatorname{Prl}$ e a patogenicidade contra Anticarsia gemmatalis. $O$ crescimento do fungo foi realizado em meio mínimo contendo nitrato e suplementado com a cutícula ou exúvia de A. gemmatalis, ou com substrato não cuticular caseína. Em meio contendo nitrato, nenhuma atividade de Prl foi detectada nos sobrenadantes das culturas. Entretanto, as duas linhagens de $\mathrm{N}$. rileyi produziram Prl em meio suplementado com fonte exógena de nitrogênio, e alta atividade foi verificada na presença da cutícula do inseto. A atividade de Pr2 foi inferior à atividade de Pr1. A análise de correlação entre a atividade de Pr1 da linhagem NR458 e mortalidade de A. gemmatalis sugere uma correlação positiva para essas variáveis. A avaliação da atividade de enzimas em diferentes condições pode ajudar na compreensão do processo infeccioso de $\mathbf{N}$. rileyi em A. gemmatalis.

Palavras-chave: controle biológico, subtilisina [Pr1], tripsina [Pr2].

\section{INTRODUCTION}

The entomopathogenic fungus Nomuraea rileyi (Farlow) Samson has the potential to control caterpillars of 30 different species of lepidopteran larvae, and the caterpillars of the Noctuidae family are among the most sensitive to this pathogen (DEVI et al., 2003; SRISUKCHAYAKUL et al., 2005). N. rileyi are an important natural control agent of Anticarsia gemmatalis (Hübner) (Lepidoptera: Noctuidae), one

Instituto de Biotecnologia, Centro de Ciências Agrárias e Biológicas, Universidade de Caxias do Sul (UCS), CP 1352, 95001-970, Caxias do Sul, RS, Brasil. E-mail: nmbarros@ucs.br.*Autor para correspondência

"Faculdade da Serra Gaúcha, Os Dezoito do Forte, 2366, 95020-472, Caxias do Sul, RS, Brasil.

"IICentro de Ciências Biológicas, Universidade Estadual de Londrina (UEL), Londrina, PR, Brasil. 
of the most damaging soybean pests in the American continent (IGNOFFO, 1981). In Brazil, $N$. rileyi often prevents populations from reaching economic threshold levels in soybean, avoiding the need for insecticide applications against this pest (CORREA AND SMITH, 1975; FARIAet al., 1993).

During the infection process, the integument is a barrier that prevents fungus penetration. Proteases are enzymes that are often considered critical in facilitating the host infection process (CLARKSON \& CHANRLEY, 1996). The best known determinant of fungal entomopathogenicity is based on subtilisin-like serine protease (designated Pr1) of Metarhizium anisopliae, whose role in host invasion has been clearly demonstrated (St. LEGER et al., 1988). This enzyme is adapted to extensively degrade the insect cuticular protein (St. LEGER et al., 1987b) and has been ultrastructurally located in the host cuticle during the early stages of penetration (GOETTEL et al., 1989). Recent studies based on the analysis of expressed sequence tag (EST) revealed the expression of several subtilisin-like proteases by $\boldsymbol{M}$. anisopliae during growth on insect cuticle (FREIMOSER et al., 2003). These different subtilisins may play different roles in pathogenicity increasing the scale of adaptability to the host, or having different survival functions in several habitats under extreme ecological conditions (BAGGA et al., 2004).

A trypsin-like enzyme $(\operatorname{Pr} 2)$, which belongsto the serine protease group, also occurs during the early stages of cuticle colonisation suggesting that it has some role in degrading extracellular proteins complementary to that of $\operatorname{Pr} 1$ (St. LEGER et al., 1996). PATERSON et al., (1994) reported that this enzyme could be involved in Pr1 activation or induction in M. anisopliae.

Both Pr1 and Pr2-like proteases are also produced by other entomopathogenic fungi, including N. rileyi (ST. LEGER et al., 1987a). This fungus may form a mucillaginous mass around the germ tube and does not usually produce appressoria (SRISUKCHAYAKUL et al. (2005), suggesting that its penetration through the larval integument occurs enzymatically, particularly during the germination of conidia. ELSAYED et al. (1993a,b) showed that this fungus produces proteases and chitinases in the presence of larval cuticle from Trichoplusia ni, Helicoverpa (Heliothis) zea, and Heliothis virescens, but not in minimal medium or on non-host substrate, suggesting that their expression is a specific response to cuticle components. Furthermore, a correlation between the level of proteases produced and pathogenicity has been reported (EL-SAYED, et al., 1993b; SRISUKCHAYAKULet al., 2005).
The entomopathogenic fungus $\boldsymbol{B}$. bassiana showed high PR1 and PR2 enzyme activities when cultured in medium containing Rhammatocerus schistocercoides grasshopper cuticle (DONATTI et al., 2008) and in medium containing Hypothenemus hampei coffee berry borer cuticle (DIAS et al., 2008).

In this study, it was examined for the first time the production of $\operatorname{Pr} 1$ and $\operatorname{Pr} 2$ proteases by $N$. rileyi in the presence of $\boldsymbol{A}$. gemmatalis cuticle, and its possible role in the process of pathogenicity and virulence to this caterpillar, extending knowledge about protease production by this fungus.

\section{MATERIALS AND METHODS}

Microorganism and culture conditions

N. rileyi strain CG434 (isolated from $\boldsymbol{A}$. gemmatalis, collected at Patos de Minas/MG, from the Entomopathogenic Fungi Collection of CENARGEN at EMBRAPABrasília/DF) and strain NR458 (isolated from A. gemmatalis, collected at Londrina/PR, from the Entomopathogenic Fungi Collection of CNPSo EMBRAPA Londrina/PR) were reinvigorated in bioassays using A. gemmatalis larvae.

Conidia were obtained by harvesting sporulated cultures grown on agar plates composed of minimal medium (MM) (PONTECORVO et al., 1953) containing nitrate as nitrogen source.

For enzyme production, conidia were added to $25 \mathrm{ml}$ of liquid MM, MMI (MM lacking nitrogen source) to which a $1 \% \mathrm{p} / \mathrm{v}$ casein solution was added (MMI+CAS), MMI to which a $0.5 \% \mathrm{p} / \mathrm{v}$ cuticle solution was added (MMI+CUT), MMI to which a solution of exuvia was added (MMI+EXU), to a final concentration of $5 \times 10^{6} \mathrm{ml}^{-1}$ and grown in submerged culture (180rpm) at $28^{\circ} \mathrm{C}$ for up to 10 days.

Cuticle and exuvia were prepared using an aqueous solution of $1 \%(\mathrm{w} / \mathrm{v})$ potassium tetraborate. The samples were taken at $0,168,192$ and 216h of growth. Mycelium was harvested by centrifugation at $8000 \mathrm{~g}$ for $15 \mathrm{~min}$ and culture filtrates were stored at $20^{\circ} \mathrm{C}$ and used as the extracellular secreted fraction. All experiments were repeated three times, and the results represent mean values $\pm \mathrm{SD}$.

Enzyme assays

Subtilisin-like $(\operatorname{Pr} 1)$ and trypsin-like $(\operatorname{Pr} 2)$ activities were determined using specific synthetic substrates as Suc-Ala-Ala-Pro-Phe- $p$-nitroanilide for $\operatorname{Pr} 1$ and N-Benzoyl-Phe-Val-Arg- $p$-nitroanilide for Pr2, according to GUPTA et al. (1992). In the reaction $50 \mu \mathrm{L}$ of substrate $(1 \mathrm{mM}), 100 \mu \mathrm{L}$ of sample and $850 \mu \mathrm{L}$ of Tris$\mathrm{HCl}(15 \mathrm{mM}) \mathrm{pH} 7.0,8.0$ and 8.5 buffer were mixed. The 
mixture was incubated for $1 \mathrm{~h}$ at $28^{\circ} \mathrm{C}$ and the reaction was terminated by adding $0.25 \mathrm{ml}$ of $30 \%$ acetic acid and left to stand for $15 \mathrm{~min}$ in ice, after which samples were centrifuged at $1250 \mathrm{~g}$ for $5 \mathrm{~min}$ at $4^{\circ} \mathrm{C}$. The supernatants were read at $410 \mathrm{~nm}$. Activities were expressed as nmol $p$-nitroanilide $\mathrm{ml}^{-1} \mathrm{~h}^{-1}$. Assays were performed in duplicate for each sample.

Virulence bioassays

The insects were placed on Petri plates with filter paper containing $3 \mathrm{~mL}$ of fungal suspensions $\left(10^{9}\right.$ conidia $\mathrm{ml}^{-1}$ ) where they stayed for approximately 24 hours. After this time they were transferred to an artificial diet. Fifty insects were used for each strain tested, and an equal number for the control with Tween $80(0,1 \% \mathrm{v} /$ v). Three repetitions were performed per treatment, and in all assays $3^{\text {rd }}$ instar caterpillars were used. The mortality rate was assessed daily until the caterpillars reached the pupal stage.

Statistical analysis

Statistical analysis of enzymatic assays was performed using parametric tests with the help of the computer program SPSS for Windows version 10.0. The data were submitted to an Analysis of variance by the ANOVA tests with media comparison using the Tukey test $(\mathrm{P}<0.05)$.

Virulence was assessed using the PROBIT method, and the $\mathrm{TL}_{50}$ was determined. The confidence interval calculated was $\mathrm{P}=0.011$ (Pearson). The Pearson Correlation Coefficient test was used to verify the level of correlation between virulence and proteolytic subtilisin-like activity (Pr1).

\section{RESULTS AND DISCUSSION}

Entomopathogenic fungi exhibit many attributes which determine virulence towards their hosts. Proteases are enzymes that are often considered critical in facilitating the host infection process (CLARKSON \& CHANRLEY, 1996).

As it is well known, growth conditions such as composition of culture medium and time could modulate the synthesis of bioactive molecules in microorganisms (RAO et al., 1998). In this study, it was determined the production of Pr1 and Pr2-like proteases by $N$. rileyi in liquid culture, either in the presence or absence of cuticular substrate at different incubation periods.

In medium containing nitrate as sole nitrogen source (MM) no detectable Pr1-like activity occurred in the culture supernatants of the two fungal strains analysed. However, both strains of $N$. rileyi produced Pr1-like protease in all medium amended with exogenous nitrogen source, and it was highly expressed in the presence of insect cuticle (Tables 1 and 2).

In medium containing casein as a source of carbon, the Pr1-like activity in the culture supernatant of both strains analysed was higher in alkaline $\mathrm{pH}$. In this culture condition, strain CG434 produced higher amounts of enzyme compared to that of strain NR458.

In the presence of cuticle substrate, strain NR458 presented greater enzyme activity, being up to 5.21U after 216h of incubation. For strain CG434, similar values of Pr 1 activity were observed in all incubation period analysed. The Pr 1 activity of strain NR458 in a culture amended with pupal exuvia was similar to the activity detected in a medium containing casein, and it was superior to that of strain CG434. Protease activity in the culture supernatant of both strains analysed was also higher in alkaline $\mathrm{pH}$ (Tables 1 and 2).

In this study, the highest expression of Pr1 was found in a medium containing a cuticle substrate compared with the other substrates, since no activity was detected in absence of exogenous protein, and low levels were observed in the casein and pupal exuvia substrates. These data suggest that components of the $\boldsymbol{A}$. gemmatalis cuticle induce the production of Pr1-like enzymes. Similarly, in previous studies, $N$. rileyi demonstrated increased proteolytic activity in the presence of Manduca sexta, Trichoplusia ni and Helicoverpa zea cuticles (ST. LEGER et al., 1987a; EL SAYED et al., 1993a). Similar results were observed for other entomopathogenic fungi (ST. LEGER et al., 1989; GUPTA et al, 1992; PATERSON et al., 1994; GILLESPIE et al., 1998; TIAGO et al., 2002; PINTO et al., 2002; CAMPOS et al., 2005; DONATTI et al., 2008; DIAS et al., 2008). Analyses of the proteolytic and chitinolytic activities of M. anisopliae and B. bassiana, performed in media containing different sources of carbon/ nitrogen and complex substrates such as colloidal chitin and cuticle of different insects showed more activities of these enzymes in the media containing complex substrates, suggesting that the expression of the genes involved in the synthesis of $\operatorname{Pr} 1$ and $\operatorname{Pr} 2$, as well as that for chitinases, depends on the level of carbon and nitrogen sources in the culture medium (MORAES, et al., 2003; CAMPOS, et al., 2005, TIAGO et al., 2007; DONATTI et al., 2008).

It was also determined the production of Pr2-like protease by $\boldsymbol{A}$. gemmatalis in liquid culture, either in the presence or absence of cuticular substrate. This activity was significantly inferior to Pr1-like activity, and it was detected only in some of the culture media and incubation periods tested (data not shown). In the culture supernatant of strain NR458, in a medium 
Table 1 - Subtilisin-like (Pr1) activity of Nomuraea rileyi NR458 after growth in different carbon sources.

\begin{tabular}{|c|c|c|c|}
\hline \multirow{3}{*}{ Time(h) } & \multicolumn{3}{|c|}{ Strain NR458 } \\
\hline & 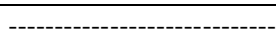 & $-\mathrm{MMI}+\mathrm{CAS}-$ & --------------------------- \\
\hline & $\mathrm{pH} 7.0$ & pH 8.0 & $\mathrm{pH} 8.5$ \\
\hline 168 & Zero & $0.263 \pm 0.14^{\mathrm{a}}$ & $0.379 \pm 0.22^{\mathrm{a}}$ \\
\hline 192 & $0.376 \pm 0.32^{b}$ & $0.420 \pm 0.17^{\mathrm{c}}$ & $0.474 \pm 0.23^{\mathrm{c}}$ \\
\hline 216 & $0.370 \pm 0.05^{\mathrm{d}}$ & $0.694 \pm 0.07^{\mathrm{e}}$ & $0.628 \pm 0.39^{\mathrm{e}}$ \\
\hline 168 & $1.694 \pm 0.64^{\mathrm{a}}$ & $\begin{array}{l}- \text { MMI+CUT-- } \\
3.707 \pm 1.98^{b}\end{array}$ & $3.321 \pm 1.90^{\mathrm{b}}$ \\
\hline 192 & $3.446 \pm 0.08^{\mathrm{c}}$ & $5.031 \pm 0.03^{\mathrm{d}}$ & $4.604 \pm 0.04^{\mathrm{d}}$ \\
\hline 216 & $4.612 \pm 0.79^{\mathrm{e}}$ & $5.210 \pm 0.11^{\mathrm{f}}$ & $4.742 \pm 0.62^{f}$ \\
\hline 168 & $0.246 \pm 0.03^{\mathrm{a}}$ & $0.339 \pm 0.09^{\mathrm{a}}$ & $0.420 \pm 0.10^{\mathrm{a}}$ \\
\hline 192 & $0.159 \pm 0.05^{b}$ & $0.258 \pm 0.01^{\mathrm{c}}$ & $0.395 \pm 0.07^{\mathrm{c}}$ \\
\hline 216 & $0.58 \pm 0.12^{\mathrm{d}}$ & $0.302 \pm 0.02^{\mathrm{e}}$ & $0.327 \pm 0^{\mathrm{e}}$ \\
\hline
\end{tabular}

MMI+CAS (Minimal medium lacking nitrogen source to which a $1 \% \mathrm{p} / \mathrm{v}$ casein solution.

MMI+CUT (Minimal medium to which a $0.5 \% \mathrm{p} / \mathrm{v}$ cuticle solution).

MMI+EXU (Minimal medium to which a solution of exuvia).

The values are expressed in $U$ (nmol of r-nitroanilide. $\left.\mathrm{mL}^{-1} \mathrm{~min}^{-1}\right)$. Means followed by the same letter do not differ from each other, at each culture time evaluated by the Tukey test $(\mathrm{P}<0,05)$

containing cuticle substrate, Pr2-like activity was found in all three periods evaluated at $\mathrm{pH}$ 8.5. In the other culture media tested, activity was found only at $\mathrm{pH} 4.0$. The highest activity was observed $(0.370 \mathrm{U} \pm 0.224)$ in medium containing nitrate as nitrogen source; in a medium containing pupal exuvia and casein, activites were lower (up to $0.175 \mathrm{U} \pm 0.05$ and $0.146 \mathrm{U} \pm 0.043$ at $216 \mathrm{~h}$ incubation, respectively). For this fungal strain, $\boldsymbol{A}$. gemmatalis cuticle did not have a positive effect on trypsin-like protease $(\operatorname{Pr} 2)$, since it was produced in substantive amounts in defined growth substrate (nitrate medium). Similar result was observed for

Table 2 - Subtilisin-like (Pr1) activity of Nomuraea rileyi CG434 after growth in different carbon sources.

\begin{tabular}{|c|c|c|c|}
\hline \multirow{3}{*}{ Time(h) } & \multicolumn{3}{|c|}{ Strain CG434 } \\
\hline & ------------------------- & $--\mathrm{MMI}+\mathrm{CAS}$ & ------------------------ \\
\hline & pH 7.0 & pH 8.0 & pH 8.5 \\
\hline 168 & $0.632 \pm 0.57^{\mathrm{a}}$ & $0.512 \pm 0.08^{\mathrm{a}}$ & $0.59 \pm 0.09^{\mathrm{a}}$ \\
\hline 192 & $1.4 \pm 0.5^{b}$ & $0.778 \pm 0.22^{\mathrm{c}}$ & $0.728 \pm 0.18^{\mathrm{c}}$ \\
\hline 216 & $0.943 \pm 0.11^{\mathrm{d}}$ & $0.782 \pm 0.32^{\mathrm{e}}$ & $1.35 \pm 1.00^{\mathrm{e}}$ \\
\hline 192 & $3.427 \pm 0.81^{\mathrm{c}}$ & $3.048 \pm 0.57^{\mathrm{d}}$ & $4.782 \pm 0.55^{\mathrm{d}}$ \\
\hline 216 & $3.571 \pm 0.6^{\mathrm{e}}$ & $3.633 \pm 1.51^{\mathrm{f}}$ & $4.857 \pm 0.25^{\mathrm{f}}$ \\
\hline 168 & $0.213 \pm 9^{\mathrm{a}}$ & $\begin{array}{c}--\mathrm{MMI}+\mathrm{EXU}- \\
0.18 \pm 0.07^{\mathrm{a}}\end{array}$ & $0.175 \pm 0.05$ \\
\hline 192 & $0.362 \pm 0.22^{b}$ & $0.142 \pm 0.02^{\mathrm{c}}$ & $0.134 \pm 0.02^{\mathrm{c}}$ \\
\hline 216 & $0.138 \pm 0.03^{\mathrm{d}}$ & $0.188 \pm 0.11^{\mathrm{e}}$ & $0.134 \pm 0.02^{\mathrm{e}}$ \\
\hline
\end{tabular}

MMI+CAS (Minimal medium lacking nitrogen source to which a $1 \% \mathrm{p} / \mathrm{v}$ casein solution).

MMI+CUT (Minimal medium to which a $0.5 \% \mathrm{p} / \mathrm{v}$ cuticle solution).

MMI+EXU (Minimal medium to which a solution of exuvia).

The values are expressed in $\mathrm{U}$ ( $\mathrm{nmol}$ of r-nitroanilide $\mathrm{mL}^{-1} \mathrm{~min}^{-1}$ ). Means followed by the same letter do not differ from each other, at each culture time evaluated by the Tukey test $(\mathrm{P}<0,05)$.

Ciência Rural, v.40, n.9, set, 2010. 
Metarhizium anisopliae var. acridum (TIAGO et al., 2002).

Strain CG434 presented lower Pr2-like activity compared to strain NR458. In a medium to which casein was added (MMI+CAS) activity $(0.162 \mathrm{U} \pm 0.37)$ was detected only at $\mathrm{pH} 7.0$ and after $168 \mathrm{~h}$ of culture. In MM and in medium supplemented with cuticle Pr2like activity was detected only at $\mathrm{pH} 8.0(0.211 \mathrm{U} \pm 0.128$ and $0.188 \mathrm{U} \pm 0.085$, respectively). No $\operatorname{Pr} 2$ activity was detected at $\mathrm{pH}$ 8.5. Different results were described by GUPTA et al. (1992) who observed that the optimum $\mathrm{pH}$ for $\mathrm{Pr} 2$ production by $\boldsymbol{N}$. rileyi was 8.5 .

Studying the B. bassiana PR1 and PR2, DIAS et al. (2008) reported the effect of nitrogen sources and $\mathrm{pH}$ variation in enzyme regulation and the induction of the aforementioned enzymes in alcaline $\mathrm{pH}$.

According to ST. LEGER et al. (1996) Pr2like protease was secreted by $\boldsymbol{M}$. anisopliae, by the infection structures (appresoria) on the surface of $\boldsymbol{M}$. sexta cuticle and by the penetrating hypha, suggesting a complementary role of this enzyme to that of Pr 1 in degrading cuticle proteins. However, $N$. rileyi does not produce appressoria, but rather a mucillaginous mass around the germinal tube, which would also function as an adhesive and facilitate enzyme production (ALVES, 1998a).

The virulence of a fungal strain can be measured in bioassays, considering the mean time needed to kill $50 \%\left(\mathrm{TL}_{50}\right)$ of a population of insects applying a single concentration of conidia (ALVES, 1998b) In this study it was found that strain NR458 induced a higher percentage of mortality $(64.4 \%)$ with a 223-hour $\mathrm{TL}_{50}$ and strain CG434 induced 35\% mortality with a 253-hour $\mathrm{TL}_{50}$.

Correlation analysis between the percentage of mortality and Pr1-like protease activity of strain NR458 (Table 3) suggests a positive correlation of these variables in the medium containing casein and cuticle at the three pHs evaluated. As to strain CG434, the correlation analysis of these variables was low compared with that observed for strain NR458. Strain CG434 also showed a positive correlation in the medium containing casein, at the three $\mathrm{pHs}$, and in the medium containing cuticle at $\mathrm{pH} 8.5$ (Table 3 ). This correlation may indicate the importance of this enzyme in the pathogenicity process of some strains of fungus $N$. rileyi to the A. gemmatalis caterpillar, and also indicates the occurrence of genetic variability among the different strains. Controversially, VARGAS et al. (2003) did not observe a correlation between enzyme activity and the virulence of fungus $\boldsymbol{N}$. rileyi, suggesting that other factors may interfere in this process. Differences in
Table 3 - Correlation analysis (Pearson) between the percentage of mortality and the Pr1 activity of strains NR458 and CG434.

\begin{tabular}{lll}
\hline Medium/pH & Strain NR458 & Strain CG434 \\
\hline MMI+Cas pH 7.0 & $0.769^{* *}$ & $0.577^{*}$ \\
MMI+Cut pH 7.0 & $0.972^{* *}$ & $0.555^{\text {n.s. }}$ \\
MMI+Exu pH 7.0 & $0.573^{\text {n.s. }}$ & $0.243^{\text {n.s. }}$ \\
MMI+Cas pH 8.0 & $0.864^{* *}$ & $0.679^{*}$ \\
MMI+Cut pH 8.0 & $0.863^{* *}$ & $0.57^{\text {n.s. }}$ \\
MMI+Exu pH 8.0 & $0.407^{\text {n.s. }}$ & $0.49^{\text {n.s. }}$ \\
MMI+Cas pH 8.5 & $0.718^{* *}$ & $0.698^{*}$ \\
MMI+Cut pH 8.5 & $0.85^{* *}$ & $0.582^{*}$ \\
MMI+Exu pH 8.5 & $0.519^{\text {n.s. }}$ & $0.373^{\text {n.s. }}$ \\
\hline
\end{tabular}

MMI+CAS (Minimal medium lacking nitrogen source to which a $1 \% \mathrm{p} / \mathrm{v}$ casein solution).

MMI+CUT (Minimal medium to which a $0.5 \% \mathrm{p} / \mathrm{v}$ cuticle solution).

MMI+EXU (Minimal medium to which a solution of exuvia).

n.s. - not significant; * - significant $(5 \%)$; ${ }^{* *}$ - significant $(1 \%)$.

pathogenicity indicate the natural occurrence of genetic variation (ST. LEGER et al., 1992).

\section{CONCLUSION}

According to the data obtained throughout this research, following the previous detailed experimental conditions, it was detected Pr1-like protease activity in the tested $N$. rileyi strains culture supernatant. No Pr1-like activity was detected in minimum media (MM); highest activity was detected in cuticle-containing media under the three $\mathrm{pH}$ values evaluated, and the most appropriate range was between 8.0 and 8.5 for the referred enzyme activity. The Pr2-like protease activity was lower when compared to Pr1-like protease activity and it was not constantly observed in all media, with most appropriate range of $\mathrm{pH}$ values between 7.0 and 8.0. The strains NR458 and CG434 induced $64.4 \%$ and $35 \%$ mortality, with LT50 of 223 and 253 hours respectively. It was a positive correlation between the Pr1-like protease activity and virulence when the NR458 strain was tested and cultured in media with casein and host cuticle in three $\mathrm{pH}$ ranges. This positive correlation was also observed for CG434 strain when cultured in media containing casein in the three $\mathrm{pH}$ ranges and in cuticle-containing media under $\mathrm{pH} 8.5$.

The results presented in this study increase knowledge about protease production in $N$. rileyi, opening new avenues for the study of the role of secreted proteases in virulence against $\boldsymbol{A}$. gemmatalis larvae during the infection process. 


\section{ACKNOWLEDGMENTS}

This work was supported by grants and fellowships from UCS, UEL, CAPES, and FAPERGS.

\section{REFERENCES}

ALVES, S.B. Fungos entomopatogênicos. In: ALVES, S.B. (Ed.). Controle microbiano de insetos. Piracicaba: Fundação de Estudos Agrários Luiz de Queiroz-FEALQ, 1988a. p.289-371.

ALVES, S.B. Produção de enzimas. In: ALVES, S.B. (Ed.). Controle microbiano de insetos. Piracicaba: Fundação de Estudos Agrários Luiz de Queiroz-FEALQ, 1988b. p.302-303.

BAGGA, S. et al. Reconstructing the diversification of subtilisins in the pathogenic fungus Metarhizium anisopliae. Gene, v.7, p.159-169, 2004. Available from: <http://www.stlegerlab.umd.edu/ pub/Bagga2004.pdf>. Accessed: Jul. 28, 2010. doi:10.1016/ j.gene.2003.09.031

CAMPOS, R.A. et al. Boophilus microplus Infection by Beauveria amorpha and Beauveria bassiana: SEM analysis and regulation of subtilisin-like proteases and chitinases. Curr Microbiol, v.50, p.257-261, 2005. Available from: <http:// www.springerlink.com/content/r887161387650p13/>. Accessed: Jul. 28, 2010. doi 10.1007/s00284-004-4460-y.

CLARKSON, J.M.; CHARNLEY, A.K. New insights into the mechanisms of fungal pathogenesis in insects. Trends Microbiol, v.4, p.197-203, 1996. Available from: <http://www.sciencedirect.com/ science?_ob=ArticleURL\&_udi=B 6T D 0-3W25CTT$29 \&$ u se r $=10 \&$ _ c o ver D a t e $=05 \% 2$ F $31 \%$

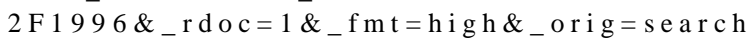
$\&_{-}$sort $=$d \&_docanchor $=\&$ vi e w $=$ c $\&$ _ a c c t $=$ C $000050221 \&$ \& version $=1 \&$ \&url Version $=0 \&$ \& us erid=10\&md5=6eda2e6a21aab82c9406532ae1e3226e>. Accessed: Jul. 28, 2010. doi:10.1016/0966-842X(96)10022-6.

CORREA, B.S., SMITH, J.G. Nomuraea rileyi attacking the velvetbean caterpillar, Anticarsia gemmatalis Huebner, in Paraná. Fla Entomologist, v.58, p.280, 1975.

DEVI, P.S.V. et al. Identification of virulent isolates of the entomopathogenic fungus $N$. rileyi (F) Samson for the management of Helicoverpa armigera and Spodoptera litura. Mycopathol, v.156, p.365-373, 2003. Available from: <http:/ /www.springerlink.com/content/m51140hu 8jk25t22/>. Accessed: Jul. 26, 2010. doi: 10.1023/B:MYCO.0000003578.38483.34.

DIAS, B.A. et al. Cuticle-degrading proteases produced by the entomopathogenic fungus Beuaveria bassiana in the presence of coffee berry borer cuticle. Braz J Microbiol, v.39, p.301-306, 2008. Available from: <http://www.scielo.br/scielo.php?pid=S151783822008000200019\&script=sci_arttext $>$. Accessed: Jul. 20, 2010. doi: 10.1590/S1517-83822008000200019.

DONATTI, A.C. et al. Production and regulation of cuticledegrading proteases from Beauveria bassiana in the presence of Rhammatocerus schistocercoides cuticle. Curr Microbiol, v.56, p.256-260, 2008. Available from: <http:// www.springerlink.com/content/m16v408g516t $3 \mathrm{gv} 0 />$. Accessed: Jul. 28, 2010. doi: 10.1007/s00284-007-9071-y.
ELSAYED, G.N. et al. Cuticular and non-cuticular substrate influence on expression of cuticle-degrading enzymes from conidia of an entomopathogenic fungus, Nomuraea rileyi. Mycopathol, v.122, p.78-87, 1993a. Available from: <http:/ /www.springerlink.com/content/q10335g663p8rn87/>. Accessed: Jul. 28, 2010. doi: 10.1007/BF01103603.

ELSAYED, G.N. et al. Effects of cuticle source and concentration on expression of hydrolytic enzymes by an entomopathogenic fungus, Nomuraea rileyi. Mycopathol, v.122, p.149-152, 1993b. Available from: <http:// www.springerlink.com/content/g2j29571x26112r7/>. Accessed: Jul. 28, 2010. doi: 10.1007/BF01103475.

FARIA, M.R. et al. Incidência natural de Nomuraea rileyi Farlow em população de Anticarsia gemmatalis Hubner no Distrito Federal. Ann Soc Entomol Bras, v.22, p.385-388, 1993.

FREIMOSER, F.M. et al. Expressed sequence tag (EST) analysis of two subspecies of Metarhizium anisopliae reveals a plethora of secreted proteins with potential activity in insects hosts. Microbiol, v.149, p.239-247, 2003. Available from: <http:// mic.sgmjournals.org/cgi/reprint/149/1/239>. Accessed: Jul. 28, 2010. doi: 10.1099/mic.0.25761-0.

GILLESPIE, A.K. et al. Role of cuticle-degrading proteases in the virulence of Metarhizium spp. for the desert locust, Schistocerca gregaria. J Invertebr Pathol, v.71, p.128-137, 1998. Available from: <http://www.sciencedirect.com/ science?_ob=ArticleURL\&_udi=B 6 WJV-45J5C6P$1 \mathrm{~T} \&$ \& user $=10 \&$ \& cover Date=03\%2F $31 \% 2$ F 199 $8 \& \_r d o c=1 \& \_f m t=h i g h \& \_o r i g=$ search\&_sort $=d \& \_d o c a n c h$ or $=\&$ view $=$ c\&_searchStrId $=1415613120$ \&_rerunOrigin $=$ google \&_acct $=$ C $000050221 \&$ \&ersion $=1 \&$ \&urlVersion $=0 \&$ \&userid $=$ $10 \& \mathrm{md} 5=44 \mathrm{e} 721$ eeb6ab0f7d368f06525a95ed26>. Accessed: Jul. 28, 2010. doi: 10.1006/jipa.1997.4733.

GOETTEL, M.S. et al. Ultrastructural localization of a cuticle degrading protease produced by the entomopathogenic fungus, Metarhizium anisopliae during penetration of host cuticle. J Gen Microbiol, v.135, p.2223-2239, 1989. Available from: <http://mic.sgmjournals.org/cgi/reprint/135/8/2233.pdf>. Accessed: Jul. 28, 2010. doi: 10.1099/00221287-135-8-2233.

GUPTA, S.C. et al. Insect cuticle-degrading enzymes from the entomogenous fungus Beauveria bassiana. Exp Mycol, v.16, p.132-137, 1992. Available from: <http://www.sciencedirect.com/ science?_ob=ArticleURL\&_udi=B 6 WFF-4HCKH2S$5 \&$ \& u s e r $=10 \&$ \& c over D a te $=06 \% 2$ F $30 \% 2$ F 199 $2 \& \_r d o c=1 \& \_f m t=h i g h \& \_o r i g=$ search $\& \_s o r t=d \& \_d o c a n c h o r$ $=\& v i e w=c \& \_s e a r c h S t r I d=1415617248 \& \_r e r u n O r i g i n=$ google $\& \_$acct $=\mathrm{C} 000050221 \&$ \& version $=1 \&$ \& urlVersion $=0 \&$ \&userid $=10 \& \mathrm{md} 5=9$ add $0398 \mathrm{a} 5 \mathrm{fb} 6 \mathrm{e} 5 \mathrm{~d} 3 \mathrm{c} 5 \mathrm{~d} 136 \mathrm{baed} 3 \mathrm{ade} 9>$. Accessed: jul. 28,2010 . doi: 10.1016/0147-5975(92)90019-N.

IGNOFFO, C.M. The fungus Nomuraea rileyi as a microbial insecticide. In: BURGES, H.D. (Ed.). Microbial control of pests and plant diseases: 1970-1980. New York: Academic, 1981. p.513.

MORAES, C.K. et al. Regulation of extracellular chitinases and proteases in the entomopathogen and acaricide Metarhizium anisopliae. Curr Microbiol, v.46, p.205-210, 2003. Available from: <http://www.springerlink.com/content/ glc3fr1ep9xjq9hd/>. Accessed: Jul. 28, 2010. doi: 10.1007/ s00284-002-3863-x. 
PATERSON, I.C. et al. Partial characterization of specific inducers of a cuticle-degrading protease from the insect pathogenic fungus Metarhizium anisopliae. Microbiology, v.140, p.3153-3159, 1994. Available from: <http:// mic.sgmjournals.org/cgi/reprint/140/11/3153>. Accessed: Jul. 28, 2010. doi: 10.1099/13500872-140-11-3153.

PINTO, F.GS. et al. Genetic variation in the cuticle-degrading protease activity of the entomopathogen Metarhizium flavoviride. Genetics and Molecular Biology, v.25, p.231-234, 2002. Available from: $<$ http://www.scielo.br/scielo.php?script=sci_arttext\&pid=S141547572002000200018>. Accessed: Jul. 20, 2010. doi: 10.1590/ S1415-47572002000200018.

PONTECORVO, G. et al. The genetics of Aspergillus nidulans. Adv Genet, v.5, p.141-238, 1953.

RAO, M.B. et al. Molecular and biotechnological aspects of microbial proteases. Microbiol Mol Biol Rev, v.62, p.597635, 1998. Available from: <http://mmbr.asm.org/cgi/reprint/ 62/3/597>. Accessed: Jul. 20, 2010.

SRISUKCHAYAKUL, P. et al. Studies on the pathogenesis of the local isolates of Nomuraea rileyi against Spodoptera litura. Sci Asia, v.31, p.273-276, 2005. Available from: <http:// www.thaiscience.info/Article\%20for\%20ThaiScience/Article/6/ Ts-6\%20studies\%20on\%20the $\% 20$ pathogenesis $\% 20$ of $\% 20$ the $\% 201$ oc a $1 \% 20$ is o 1 ates $\% 20$ of $\% 20$ nomura ea $\% 20$ rileyi $\% 20$ against $\% 20$ spodoptera $\% 201$ itura.pdf $>$. Accessed: Jul. 20, 2010.

ST. LEGER, R.J. et al. Distribuition of chymoelastases and trypsin-like enzymes in five species of entomopathogenic deuteromycetes. Arch Biochem Biophys, v.258, p.123-131, 1987a. Available from: <http://www.sciencedirect.com/ science?_ob=ArticleURL\&_udi=B6WB 5-4DPB Y B 7 H8 \&_user $=10 \&$ \&coverDate $=10 \% 2 \mathrm{~F} 31 \% 2 \mathrm{~F} 1987 \&$ \& rdoc $=1$

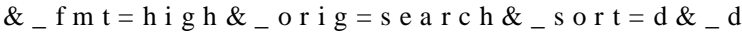
o c a n chor $=\&$ vi e w $=\mathrm{c}_{-} \&_{-}$s e a r c h S t r I d $=141$ $5629578 \&$ \&rerunOrigin $=$ google \&_acct $=C 000050221$ \&_version $=1$

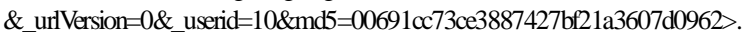
Accessed: Jul. 20, 2010. doi: 10.1016/0003-9861(87)90329-8.

ST. LEGER, R.J. et al. Characterization of cuticle degrading proteases produced by the entomopathogen Metarhizium anisopliae. Arch Biochem Biophys, v.253, p.221-232, 1987b. Available from: < h t t p : / / w w w. s c i e n c e d i r e c t. c o m/ science?_ob=ArticleURL\&_udi=B6WB 5-4DXBF3R$27 \&$ _user $=10 \&$ _coverDate $=02 \% 2$ F $15 \% 2$ F $1987 \&$ \&d $\mathrm{oc}=1 \& \_$fmt $=$high\&_orig $=$search\&_sort $=\mathrm{d} \& \_$docanchor $=\& \mathrm{view}$ $=c \& \_s e a r c h S t r I d=1415633949 \& \_r e r u n O r i g i n=$ google $\& \_a c c t=C 00$ $0050221 \&$ \&ersion $=1 \&$ \& ur 1 Version $=0$ \&_userid $=10$ \&md5=1e99a2ee9ba52fd2f235e675439a37ea>. Accessed: Jul. 28, 2010. doi: 10.1016/0003-9861(87)90655-2.

ST. LEGER, R.J. et al. Regulation of production of proteolytic enzymes by entomopathogenic fungus Metarhizium anisopliae.
Arch Microbiol, v.150, p.413-416, 1988. Available from: <http://www.springerlink.com/content/w718685w21603tu1/>. Accessed: Jul. 28, 2010. doi: 10.1007/BF00408316.

ST. LEGER, R.J. et al. Synthesis of proteins including a cuticledegrading protease during differentiation of the entomopathogenic fungus Metarhizium anisopliae. Exp Mycol, v.13, p.253-262, 1989. Available from: <http:// www.sciencedirect.com/science?_ob=ArticleURL\&_udi=B6WFF4J0X39P-6\&_user $=10 \&$ \&coverDate $=09 \% 2$ F30\%2F1989\& _rdoc $=1 \&$ _fmt $=$ high\&_orig $=$ search\&_sort $=$ d\&_docanchor $=\&$ view $=$ c\&_searchStrId=1415638294\&_rerunOr igin $=$ google\&_acct $=$ C000050221\&_version $=1 \&$ \&urlVer sion $=0 \& \_u s e r i d=10 \& m d 5=754 \mathrm{ef} 525 \mathrm{~d} 82418 \mathrm{c} 04 \mathrm{~b} 117 \mathrm{~b} 1 \mathrm{cde} 348 \mathrm{~d} 2 \mathrm{e}>$. Accessed: Jul. 28, 2010. doi: 10.1016/0147-5975(89)90047-9.

ST. LEGER, R.J. et al. Genetic differences in allozymes and in formation of infection structure among isolates of the entomopathogenic fungus Metarhizium anisopliae. J Invertebr Pathol, v.60, p.89-101, 1992. Available from: $<\mathrm{ht} \mathrm{t} \mathrm{p} \mathrm{:} \mathrm{/} \mathrm{/} \mathrm{w} \mathrm{w} \mathrm{w.} \mathrm{s} \mathrm{c} \mathrm{i} \mathrm{e} \mathrm{n} \mathrm{ce} \mathrm{d} \mathrm{i} \mathrm{re} \mathrm{c} \mathrm{t} \mathrm{c} \mathrm{o} \mathrm{m} \mathrm{/}$ science?_ob=ArticleURL\&_udi=B6WJV-4F1SV8VD 6\&_user $=10 \&$ \& coverDate $=07 \% 2$ F 3 1\% 2F $1992 \&$ _rdoc $=1 \& \_$fmt $=$high $\&$ orig $=$ search\&_sort $=$ d\&_docanchor $=\&$ vie $\mathrm{W}=\mathrm{c} \& \_s e a r c h S t r I d=1415640110$ \&_rerunOrigin $=$ google \&_acct $=\mathrm{C} 000$ 050221 \&_version $=1 \&$ \&ur 1 Version $=0 \&$ \& userid $=$ $10 \& \mathrm{md} 5=45 \mathrm{ad} 88 \mathrm{~d} 03446 \mathrm{dbdb} 508672865 \mathrm{a} 287 \mathrm{~d} 5 \mathrm{a}>$. Accessed: Jul. 28, 2010. doi: 10.1016/0022-2011(92)90159-2 .

ST. LEGER, R.J. et al. Biochemical characterization and ultrastructural localization of two extracellular trypsins produced by Metarhizium anisopliae in infected insect cuticles. Appl Envirom Microbiol, v.62, p.1257-1264, 1996. Available from: <http://www.ncbi.nlm.nih.gov/pmc/articles/PMC167891/pdf/ 621257.pdf>. Accessed: Jul. 20, 2010.

TIAGO, P.V. et al. Cuticle-degrading proteases from the entomopathogen Metarhizium flavoviride and their distribuition in secreted and intracellular fractions. Lett Appl Microbiol, v.34, p.91-94, 2002. Available from: <http:// www3.interscience.wiley.com/cgi-bin/fulltext/118950047/ PDFSTART >. Accessed: Jul. 20, 2010. doi: 10.1046/j.1472765x.2002.01064.x.

TIAGO, P.V. et al. Proteolytic activity of Metarhizium anisopliae isolates on cuticular and noncuticular substrates. Cienc Rural, v.37, p.26-30, 2007. Available from: <http:// www. scielo.br/scielo.php? script $=$ sci_arttext\&pid $=$ S0 103 84782007000100005>. Accessed: Jul. 20, 2010. doi: 10.1590/ S0103-84782007000100005.

VARGAS, L.R.B. et al. Characterization of Nomuraea rileyi strains using polymorphic DNA, virulence and enzyme activity. Braz Arch Biol Technol, v.46, p.13-18, 2003. Available from: 〈http://www.scielo.br/pdf/babt/v46n1/a03v46n1.pdf〉. Accessed: Jul. 20, 2010. doi: 10.1590/S151689132003000100003 . 